Behnaz Rafiei Moghadam, PhD Student, E-mail: bhnzrafiei@gmail.com; Khalil Rezaei, Assist. Prof., E-mail: drkhalilrezaei@gmail.com; Ali Solgi, Assoc. Prof.

E-mail: Asolgi66@yahoo.com; Pantea Ghiahchi, Instructor,

E-mail: aleali.mohsen@gmail.com; Mohsen AleAli, Assist. Prof., E-mail: pgiahchi@gmail.com; Tehran, Iran

\title{
GRADATION AND GEOCHEMISTRY OF THE FENCED LAGOON SEDIMENTS (BANDAR ANZALI) WITH REGARD TOWARDS SOURCE ROCK AND TECTONIC LOCATION
}

\begin{abstract}
(Представлено членом редакційної колегії д-ром геол. наук, проф. О.М. Іванік)
The location of the Fenced Lagoon in the urban basin of Bandar Anzali, which should be considered due to its impact on the lives of the people of the region in terms of the conservation of the wetland and its environmental issues, and, on the other hand, the potential of this area to be introduced as a geotourism center determine the need to investigate the area's sedimentology and geochemistry. Therefore, to study sedimentary and geochemical properties of the Fenced Lagoon sediments located in Bandar Anzali, 33 samples were taken in the form of 6 cores and 12 grabs, andbasic sedimentation tests and heavy metals measurement were carried out through XRF. Studies show that the sediments are ranged from sand to clay in terms of gradation and have mainly costal-river origin. The sediments of this lake are classified into four sedimentary types: Muddy Sand, Slightly Gravely Muddy Sand, Sand and Slightly Gravely Sand and sand is the main component of all of these sediments. The most abundant sedimentary types belong to Muddy Sand and Sand and the least abundant sedimentary types belong to Slightly Gravely Muddy Sand and Slightly Gravely Sand. The nature of the source rock is derived from acidic to intermediate combination and in general, sedimentary rocks of the area under study are within the continental arch islands and, to a lesser extent, the active continental margin.
\end{abstract}

Keywords: Anzali port, sediment, sedimentary geochemistry, measurement of metals, origin, tectonic location.

Introduction. Coastal wetlands provide a wide range of natural services that are socially valuable (Gonenc and Wolfin, 2005), including fishing, tourism and even storm control (Abigail et al., 2009). Maintaining these valuable environments depends on precise study and recognition. Obviously, their economic productivity and maintenance are impossible environmentally without the recognition and study of the wetlands (Abdollahi, 2010). The southern Caspian basin also has several wetlands that require studies from different perspectives.

The Caspian Sea and its rapid fluctuations at sea level during the Holocene have been the subject of many studies over the past two decades (Lahijani et al., 2009; Leroy et al., 2011; Kakroodi et al., 2012; Naderi Beni et al., 2013). The Caspian Basin, after separating from the open sea, became a lake at the time of Pliocene, and from then on, a series of tectonic activities, fluctuations in water levels, wave effects and their flows, and rivers, made its morphology in the present way (Naderi Beni and Lahijani, 2014). Climate is the most important reason for changes in the water level of the Caspian (Kroonenberg et al., 2007; Naderi Beni et al., 2013; Leroy et al., 2013). These fluctuations at sea level have different impacts on costal evolution and relatively on coastal deposits (Naderi Beni et al., 2013) that are recorded in coastal deposits (Tamura et al., 2008).

Changes in the level of Caspian Sea waters may result from a factor or a combination of factors, such as climate change, tectonic processes, and human activity. The impact of each of these factors is not the same as an effective factor in overall changes in the water level. Obviously, any change on the Caspian Sea has a direct impact on its marginal wetlands and the performance of river systems. Changes in such habitats will have a direct impact on the morphology and animal life and even the coastal economy. Moreover, considering that wetlands are usually influenced by sea and river forces, and changes in the dynamics of seas and rivers affect them, recognizing these effects and various anomalies in heavy elements when they enter the wetland and deposit in it are very important both ecologically and economically (Ranjbar, 2012). The sediments of wetlands are the main components of our environment and an important source of cadmium, organic and chemical substances that can be resulted from natural processes and erosion or created by human intervention. In addition, coastal wetlands play an important role in trapping river sediments and nutrients and reduce their transmission to seas. Of course, the pattern of human activities in the use of land, such as agriculture and urban planning and the way of land use have made a lot of changes in this important issue (Bruland et al., 2010). Wetlands also play an effective role in preventing flood occurrence and act as a sedimentary slab (Kazanci et al., 2004). Since climate change and human interventions have caused many of the country's wetlands to dry out, if wetlands are studied comprehensively and properly, this environmental catastrophe can be controlled largely and the destructive effects of this process can be minimized.

Due to the environmental importance of this wetland and Anzali area in general, various studies have been carried out in this area in recent years. For instance, Kowsari did semidetailed explorations in the area in relation to titanium in the region in 1991. Shahabi published a book on the seas and lakes of Iran in 1994 in which the significance of this wetland is also mentioned. A compilation report of the studies on water resources of the Sefid Roud basin was prepared in 2001 by Gilan Regional Water Company. Other studies in this area include the geological map of Bandar-e-Anzali, prepared by Mousavi-Harami (2006) and Khabaznia et al. (2005) to better understand this water basin. Then, to complete them, Kheiri (2005) presented a report on remote sensing of Bandar Anzali plate with special attention to the marine geology and morphology of the Caspian region. Karim Khani (2007), prepared a report on the sedimentology and sedimentary geochemistry of the sea plate of Bandar Anzali, and the latest research in this area was carried out by Ms. Hazer Moshar (2015), as the doctorate dissertation, which has not been published yet.

Despite the presence of the Fenced Lagoon inside the city of Anzali and its impact on the lives of residents around it, no comprehensive study has been carried out so far on the sedimentology of this area. Therefore, this study seeks to achieve this goal.

Geographical Location and Sampling Points. The Fenced Lagoon is about $240 \mathrm{~m}$ in length and in the broadest place $40 \mathrm{~m}$ wide at latitude $4147855 \mathrm{~N}$ and longitude $365152 \mathrm{E}$ and is located in the southeast of Anzali wetland and in the north of fire department of Ghazian district and in 
the city of Anzali. The elevation of the lake is $24 \mathrm{~m}$ from the sea level, the area of the lake is $29353 \mathrm{~m}^{2}$ and itsperimeter is $1137 \mathrm{~m}$. This area is located in the $1: 100,000$ Anzali rectangular maps. In the past, this wetland was part of the Caspian Sea drainage basin, which was running to the Anzali wetland through a water slab. Surface waters and seasonal and winter rainwaters flowed into the pond after crossing various areas. At present and in the summer, its water content decreases, which somewhat plays the role of the drainage of the area. The wetland is surrounded by residential houses and private estates.
For this research, after collecting the data and office studies, the wetland area was first determined using aerial photos and satellite imagery using ArcGIS software. Then the sampling points were determined according to the extent of the wetland (Fig. 1).

Materials and Methods. Sampling at the surface of the wetland was carried out based on previous findings and data, which consisted of 33 specimens in the form of six cores, the cores were taken by polyethylene pipes, and 12 samples of the deposits in the wetland floor taken by the grab (Fig. 2).

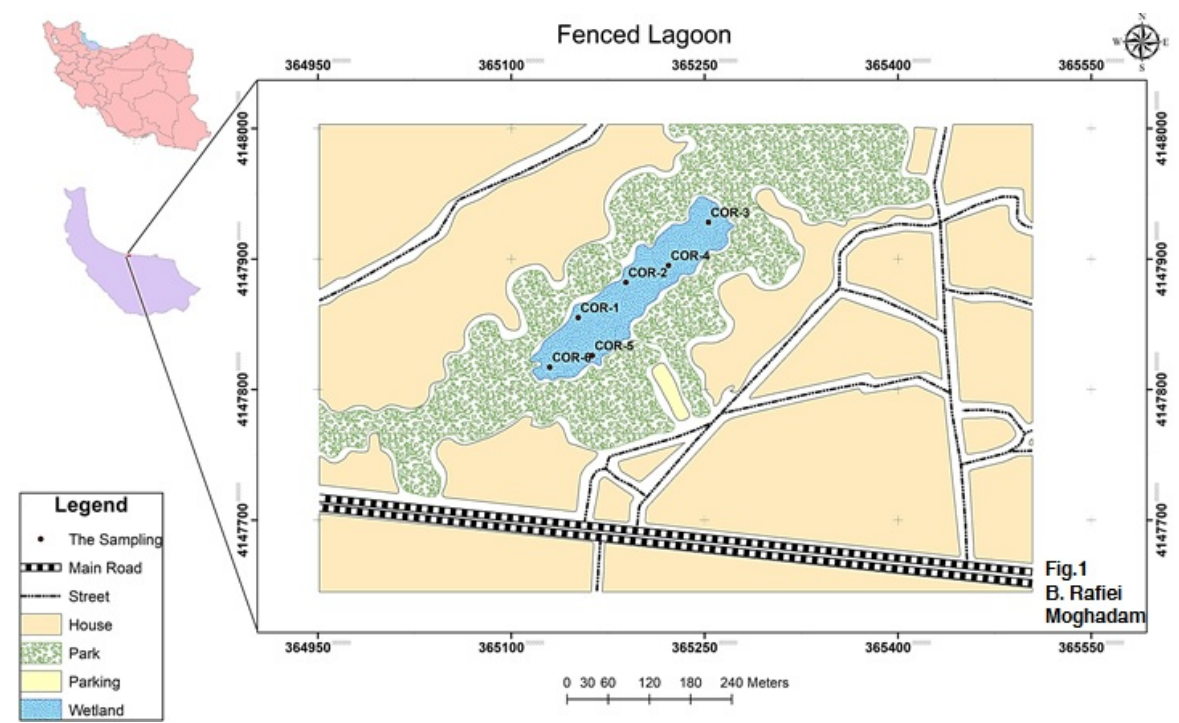

Fig. 1. Geographical location of the Fenced Lagoon and the sampling points

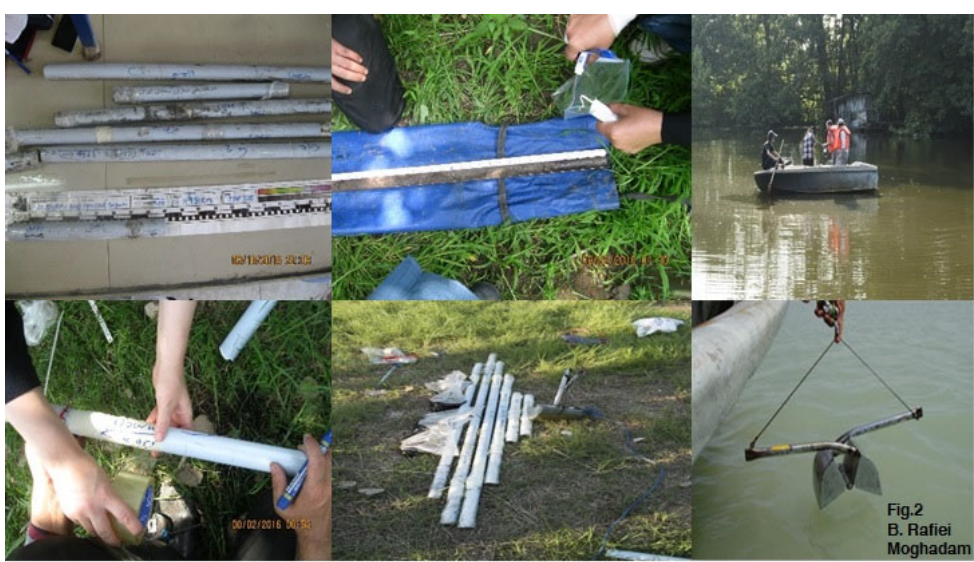

Fig. 2. Coring the wetland using polyethylene pipes, and packing and recording the cores (left), and sampling by grab (right)

Samples Preparation. After transferring the specimens to the laboratory and freezing them, the sedimentary cores were separated from the polyethylene tubes by a stone milling machine, so that half of the core thickness was still in the tube. At this point, care must be taken to prevent the contact of metal blade of the milling machine with the cores (Fig. 3).

The specimens inside each core were separated according to color change and sedimentation and were accumulated and numbered in individual containers. Experiments performed on the samples included gradation, hydrometry, XRF and ICP. There are several methods for measuring the diameter of the grains (Mousavi-Harami, 2006). Dry sieve method was used in this study. After drying, the sample were weighed and dried through sieving and were graded by the shaker (Anderson and Krysell, 2005). The results of gradation were used to obtain the statistical factors and the comprehensive Folk
(1980) drawing method was used for the particles sedimentology such as sorting, tilting and stretching, and the population of suspension, mutation and deflection of sediments, as well as their turning point were calculated using cumulative diagram. Then, the frequency percentage chart of the particles was plotted using GRADISTAT software (Blott and Pye, 2001). In the following, using Folk's (1954) method, four facial types were identified and using Rockwork software, facies columns were depicted based on the depth and this information was used to interpret and comment the sedimentary environment and their vertical and lateral changes. For gradation of clay and salt particles (below 63 microns) is the hydrometric method the best method in which the particles' diameter is obtained according to Stokes's law (Faiz Nia, 2008). Hydrometric experiments were carried out on 3 cores and 2 crop samples, then parameters such as creep rate, time, 
particle diameter and ultimately transition and cumulative percentages were calculated and diagrams were plotted based on the cumulative percentage and particle diameter in $\mathrm{F}$ and the results were analyzed.
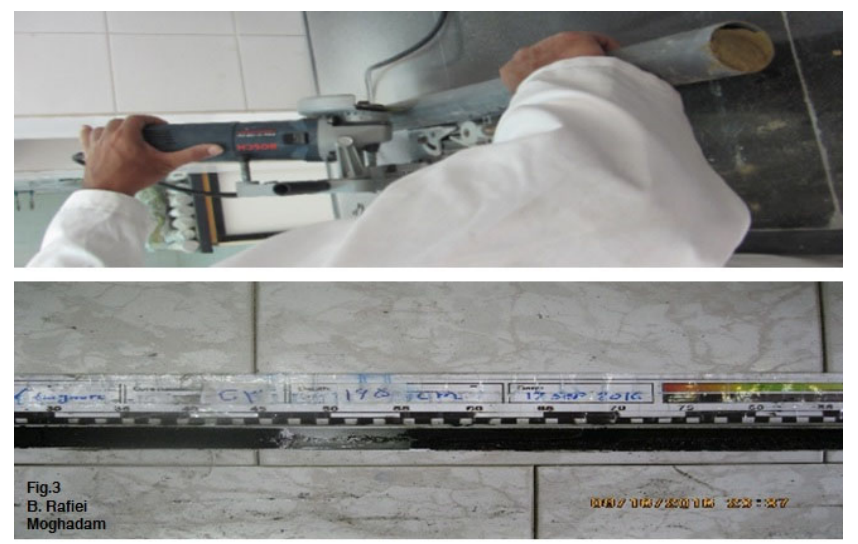

Fig. 3. Cutting of polyethylene pipes by means of milling machine (above) and sedimentary cores after cutting (below)

After the sedimentation steps, a geochemical method was used to analyze the samples and determine the forming oxides and to identify the minerals in the sediments. Many geochemical methods, despite the high resolution, are very time consuming and cause the waste of the sediment. Therefore, in this research, the non-destructive XRF method was used (Jansen et al., 1998; Rohl and Abrams, 2000). This method is widely used in the Dutch Texel Research Institute for measuring the intensity of heavy elements (Bahr et al., 2005). For this purpose, all 45 samples were sent to the laboratory of the Geological Survey and Mineral Exploration of Iran and the elements in the samples were analyzed. Then, using the multivariate graphs, the origin of the wetland sediments was obtained.

Discussion. Gradation Studies.

Grain size is one of the most important characteristics of sedimentary particles that is affected by their transfer and sedimentation (Folk and Ward, 1957). Therefore, analyzing particle size and shape gives us important clues about the origin of sediment, transport history and sedimentation conditions. Since the obtained results may not be directly comparable using different methods, and the analysis of the obtained data by using more than one method may be difficult (Pye, 1994), the obtained data and the results of 6 cores and 12 samples of grab were investigated in this research using GRADISTAT software. By determining the percentage of particles with different diameters in the described method, the sediment was named according to the Folk method (1954). Despite the low percentage of gravel in samples, since the abundance of coarse grains in sediments, even to a negligible amount, is valuable for interpreting the energy and the type of the environment (Mousavi-Harami, 2006), it was considered in sediments classification and environment determination. According to the Folk method (1954), the sediments of this lake were divided into four sedimentary types including Muddy Sand, Slightly Gravely Muddy Sand, Sand, Slightly Gravely Sand, and sand is the main component of all these sediments. The most abundant sedimentary types belong to Muddy Sand and Sand and the least abundant sedimentary types belong to Slightly Gravely Muddy Sand and Slightly Gravely Sand. The frequency of Muddy Sand is mainly seen in surface sediments up to the depth of $100 \mathrm{~cm}$, while the facies type of Slightly Gravely Muddy Sand is related to grater depths and both facies are more abundant in the north and northeast parts of the lake. By moving to the south and southwest regions of the lake, the two facies of Sand and Muddy Sand become more abundant (Fig. 4). The size of sediment particles increases as the depth decreases from northeast to southwest. Alternate layers of sand - mud and sand horizons containing shellfish represent the periods of relaxation of the lagoon and its relationship with the sea (Ghazban, 2011).

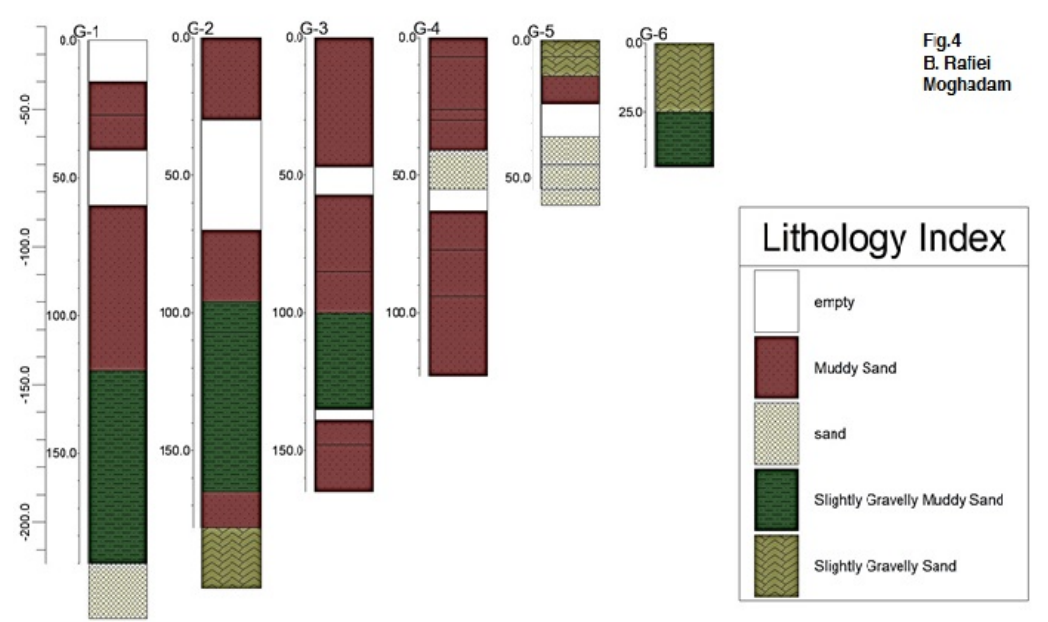

Fig. 4. Stratigraphic column of Fenced Lagoon Sediments

The range of elongation in the sediments of the studied basin is between 0,63 and 1 . In other words, the elongation of sediments in different cores varies from very broad to broad, medium and stretched, which is more toward broader grains indicating that the curve trail (silt, clay and gravel) has a better alignment than the middle part of the curve (Faiz Nia, 2008). In most of the rivers with bed load, it is shown that with better alignment downwards, the cumulative curve 
elongation increases (Mousavi-Harami, 2006). The majority of the samples in the basin have bad to moderate alignment (between 0,5 to 1,7 ). This situation usually represents the flow turbulence that is probably due to the arrival of seasonal flow of rivers into the basin (Paseban, 2012). The range of tilting variations in the studied sediments varies between 0,6 and 0,3 . Of these, only six samples taken with the grab have positive tilting and the rest have negative tilting. Positive tilting indicates a greater frequency of fine-grained sediments, possibly due to the presence of these particles between coarser-grained sediments (Paseban, 2012). Of course, the turbulence of the feeding currents of the area, erosion and crushing of coarse-grained sediments, and unstable grains that lead to the production of smaller sediments, are also the causes of positive tilting (Rice, 1999). Negative tilting also means an increase in coarsegrained particles, which can be seen on shores where the reciprocating waves are active and fine particles are removed (Faiz Nia, 2008).

Gradation changes in this basin, including changes in grain size and changes in statistical parameters such as sorting and rounding and flattening can indicate the intensity of changes in the feeding currents of the area and lithology changes in the region. Non-continuous changes in the particles size indicate the role of subordinate feeding branches in supplying sediment in this basin.

Geochemical Studies.

One of the most reliable methods to identify the source rocks and separate sediments is the use of geochemical data in the separation of the main and secondary elements. Many researchers have carried out geochemical studies to determine the origin of sediments in the wetlands, their water quality, as well as the pollutants contained in them (Amini, 2012). In the meantime, the volume of studies carried out on Anzali wetlands and its surrounding wetlands is remarkable because of its importance as an international wetland.

Swamps and bays of the Caspian margin are formed under three main processes of longitudinal transmission of coastal sediment, elevation of the Caspian Sea and anticline-syncline structures (Leontiev, 1977), and are considered the environment of the land-to-sea transition. These environments, which are semi-closed with sandy slabs or structural complications, provide a relatively lowenergy environment for sedimentation (Leeder, 1982), thus in addition to being influenced by the marine environment, they are affected by the catchment area and surrounding shores as well.

In general, geochemical data of the main and secondary elements can be used for chemical classification of rocks, determination of the prevailing weathering conditions of sedimentary rocks, separation of adult sediments from immature, determination of the source rock and the main tectonic position of igneous rocks and some sedimentary rocks (Rollinson, 1993). The study of the main elements is often limited to 10 elements, $\mathrm{Ca}, \mathrm{Na}, \mathrm{K}, \mathrm{P}, \mathrm{Ti}, \mathrm{Al}, \mathrm{Fe}, \mathrm{Mn}, \mathrm{Mg}$ and $\mathrm{Si}$, which are conventionally expressed as oxidation in XRF chemical decomposition. Controlling processes of the elements in sedimentary rocks can be studied using the normalization diagrams similar to the spider diagrams (Rollinson, 1993).

The main part of the Caspian coastline is covered with delta, river and coastal sediments of the present day (Agha Nabati, 2004). The present sediments of the study area include the granitoid complex remain between the hardened sediments Attributed to continental - sea climates of the Quaternary (Alavi, 1996). Based on geochemical similarities and previous studies (Nazari et al., 2004), this granitoid is comparable to Lahijan granites. This unit itself is located on older sediments, including sedimentary-deltaic facies of the sub-intertidal zone of the upper Triassic, lower Jurassic to early Cretaceous, deposited in various tectonic climates. The most ancient rocks in the area under study are also a row of destructive rocks, sandy shale and thin to middle layer sandy argillaceae of olive green, which can be considered equal to the upper part of the Mila Formation or the middle section of the Lalun Formation (Alavi, 1996).

The results of the analysis of the elements in the deposits of various sedimentary cores of the wetland are displayed in Fig. 5.

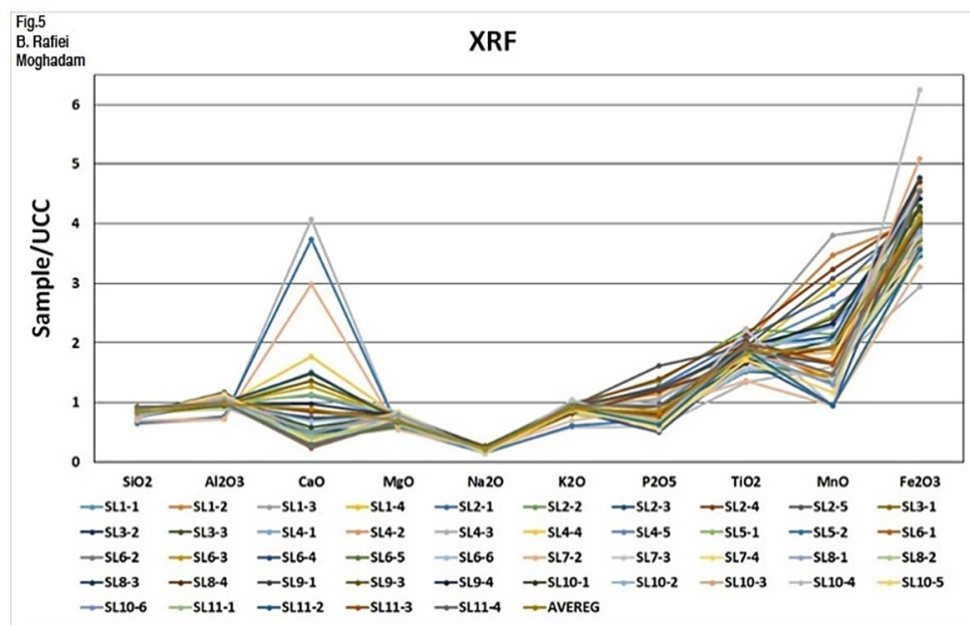

Fig. 5. Spider diagram of the main oxides and secondary elements normalized with the combination of upper Talor and McLennan (1985) continental crust (UCC, 1985) based on geochemical data of the Fenced Lagoon sediments

Before examining the results of the geochemistry on the commonly used charts and their interpretation, it is necessary to analyze the statistical processing of the decomposition of the main and secondary elements of the cores. As shown in the table, the mean SiO2 content of the Fenced Lagoon sediments $(61,37 \%)$ is approximately equal to the mean SiO2 content of the continental crust (Taylor and McLennan, 1985; $\mathrm{SiO}_{2}=64 / 8$ ). Moreover, the mean
$\mathrm{CaO}$ content of the wetland sediment $(1,4 \%)$ is about twice as much as the $\mathrm{CaO}$ content of the upper crust (4.19), which indicates high amount of fine stones and carbonate cement, causing a relative reduction in $\mathrm{SiO}_{2}$ and $\mathrm{Al}_{2} \mathrm{O}_{3}$ percentage. The amount of $\mathrm{K}_{2} \mathrm{O}$ and $\mathrm{Na}_{2} \mathrm{O}(1,55$ on average) is higher than that of the continental crust that can indicate the presence of feldspar in the samples. A higher percentage of 
$\mathrm{Fe}_{2} \mathrm{O}_{3}$ and $\mathrm{MgO}$ oxides, as compared to the upper continental crust, may also represent mafic minerals.

Since $\mathrm{Al} 2 \mathrm{O} 3$ is almost unchanged during weathering, diagenesis and transformation, it can be used as an appropriate factor for comparison with other major elements. (Therefore, in order to investigate the geochemical position of the main and rare elements in the sand and mud sediments of the Fenced Lagoon, the frequency diagrams of the oxides of the main elements have been used against $\mathrm{Al}_{2} \mathrm{O}_{3}$ (Afarin et al., 2014). The changes trends of the oxides of the main and trace elements against $\mathrm{Al}_{2} \mathrm{O}_{3}$ indicate that the sediments under study can be classified into two general groups of sand and mud. In Fig. 6, the relationship between $\mathrm{Al}_{2} \mathrm{O}_{3}$ and $\mathrm{K}_{2} \mathrm{O}, \mathrm{Fe}_{2} \mathrm{O}_{3}, \mathrm{MgO}, \mathrm{TiO}_{2}$ and $\mathrm{SiO}_{2}$ is positive and it does not show a significant relationship with $\mathrm{MnO}, \mathrm{CaO}$, $\mathrm{Na}_{2} \mathrm{O}, \mathrm{K}_{2} \mathrm{O}$ and $\mathrm{P}_{2} \mathrm{O}_{5}$. The positive relationship between $\mathrm{Al}_{2} \mathrm{O}_{3}$ and $\mathrm{Fe}_{2} \mathrm{O}_{3}$ and $\mathrm{K}_{2} \mathrm{O}$ can be due to the presence of these elements in clay and mica minerals. Furthermore, $\mathrm{K}_{2} \mathrm{O}$ can represent a rich aluminum phase, especially illite, or concentration of potassium minerals in samples LEE (1999); DAS et al., (2006). Since the amount of clay in stone background is low in sand samples, the $\mathrm{K}_{2} \mathrm{O}$ content is probably related to clay minerals found in shale specimens. The positive association of $\mathrm{Al}_{2} \mathrm{O}_{3}$ and $\mathrm{SiO}_{2}$ indicates the presence of feldspar and mica and clay minerals. Increasing $\mathrm{TiO}_{2}$ with $\mathrm{Al}_{2} \mathrm{O}_{3}$ indicates the association of $\mathrm{TiO}_{2}$ or phyllosilicates, especially illite (Dabard, 1990). High percentage of $\mathrm{CaO}$ indicates that the samples can contain carbonate, and calcite, in particular. A relatively high proportion of $\mathrm{K}_{2} \mathrm{O} / \mathrm{Na}_{2} \mathrm{O}$ (especially in shale) can be attributed to the presence of albicagmatic plagioclase, feldspar potassium of mica and illite (Pettijohn et al., 1987; McLennan et al., 1993; Nath et al., 2000).

The main elements during weathering, transport and diagenesis can be used to determine the degree of maturation of sediments (McLennan et al., 1993). A low amount of $\mathrm{Na}_{2} \mathrm{O}$ in the studied sandstone can be attributed to their high maturity. In addition, the $\mathrm{SiO}_{2} / \mathrm{Al}_{2} \mathrm{O}_{3}$ ratio is also an indicator used to determine maturity. This amount increases during weathering, transport and re-cycling as a result of quartz increase over unstable parts such as feldspar and rocky parts. A greater proportion of 5 to 6 in sediments and sedimentary rocks represent the high maturity of sediment or rock. (Roser and Korsch, 1988) The average of this fraction in the studied samples is less than one, which indicates the immaturity of these sediments; this is also characterized by high $\mathrm{Na}_{2} \mathrm{O}$ content.

Multiple plot of $\mathrm{Al}_{2} \mathrm{O}_{3}$ vs. $\mathrm{SiO}_{2}, \mathrm{CaO}, \mathrm{MgO}, \mathrm{Na}_{2} \mathrm{O}, \mathrm{K}_{2} \mathrm{O}, \mathrm{P}_{2} \mathrm{O}_{4}, \mathrm{TiO}_{2}, \mathrm{Fe}_{2} \mathrm{O}_{3}, \mathrm{MnO}$
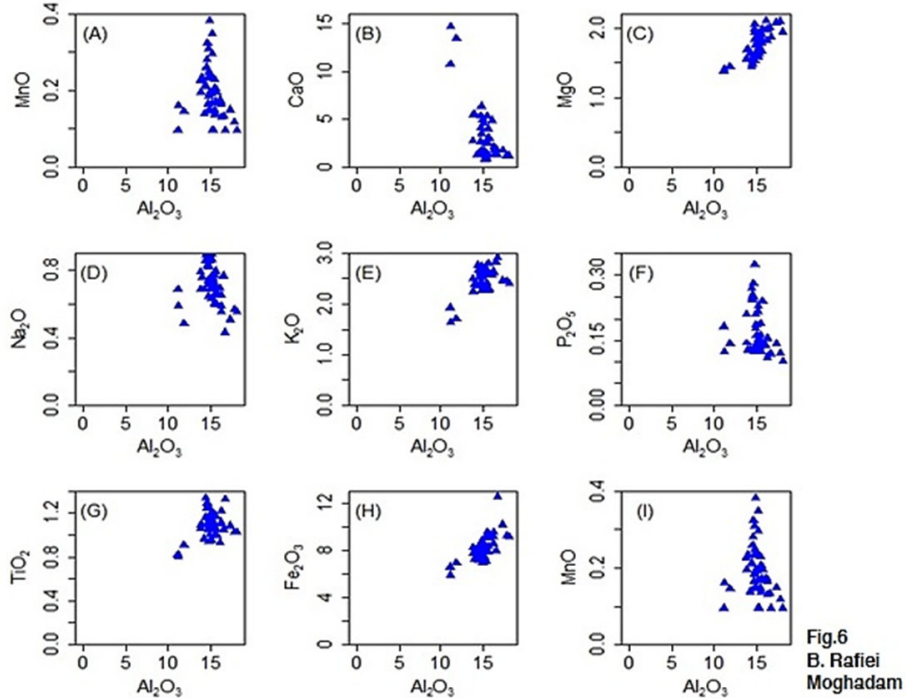

Fig. 6. Chart of changes of some of the oxides of the main and secondary elements against the weight percent of $\mathrm{Al}_{2} \mathrm{O}_{3}$ in order to study the geochemical status of the main and rare elements in the Fenced Lagoon sediments

\section{Source Rock}

Geochemistry of sediments can play an important role in determining the source and mother rock and climatic conditions of sediments. The analysis of secondary elements, as well as major oxides such as $\mathrm{Al}_{2} \mathrm{O}_{3}$ and $\mathrm{TiO}_{2}$, is very important for the interpretation of sediments (Katemaunzanga and Gunter, 2009; Maslov, 2011). For example, trace elements such as barium, lanthanum, vanadium, zirconium in sediments provide researchers with important information about mother rock of the sediments, and using different techniques such as the use of triangular and dual diagrams can provide useful information on wetlands (Lak, 2015).

In this regard, many classifications can reveal the origin of deposits. For example (Maynard et al., 1982; Bhatia, 1983; Bhatia and Crook, 1986; Roser and Korsch, 1986) the methodology used for this study is presented by Roser and Korsch (1988), which helps us recognize four kinds of sediments origins in four different zones including Mafic, Intermediate, Felsic and Depositional Quartz. These diagrams are obtained from the total oxides of $\mathrm{Ti}, \mathrm{Al}, \mathrm{Fe}, \mathrm{Mg}$, $\mathrm{Ca}, \mathrm{Na}$ and $\mathrm{K}$. The advantage of using this method is that one can ignore the percentage of biogenic $\mathrm{SiO}_{2}$ and $\mathrm{CaO}$ and consider the percentage of the oxide of other elements against $\mathrm{Al}_{2} \mathrm{O}_{3}$ while using these diagrams to determine the source Roser and Korsch (1986). With respect to (Fig. 7), the obtained samples show a gradual transition from mafic to intermediate igneous origin. Samples containing shale are well plotted in mafic zone (Roser and Korsch, 1988). It seems that the ratio of $\mathrm{Al}_{2} \mathrm{O}_{3} / \mathrm{TiO}_{2}$ in shale is similar to that of source rocks and can therefore be used as an indicator of origin. (Hayashi et al.,1997) . Hayashi et al insist that A ratio of above 21 could indicate the felsic origin. This average in our research was between 16,93 and 20,67, which could indicate the origin of the combination of mafic to intermediate. It should be added that the distribution of metal elements in sediments around the Caspian Sea region suggests that, in some cases, such as barium, their concentration is more than the amount of the ground, which indicates their entry through human activities, although most 
of them are supplied through destructive deposits of the watershed (Lahijani et al., 2009). Comparison of metal composition of surface sediments with deep sediments of the same area in terms of chemical composition can indicate the geochemical background of the region (Karageorgis et al., 2006; Buccolieri et al., 2006; Muller and Groves, 1993, Adams and Keller, 1994).

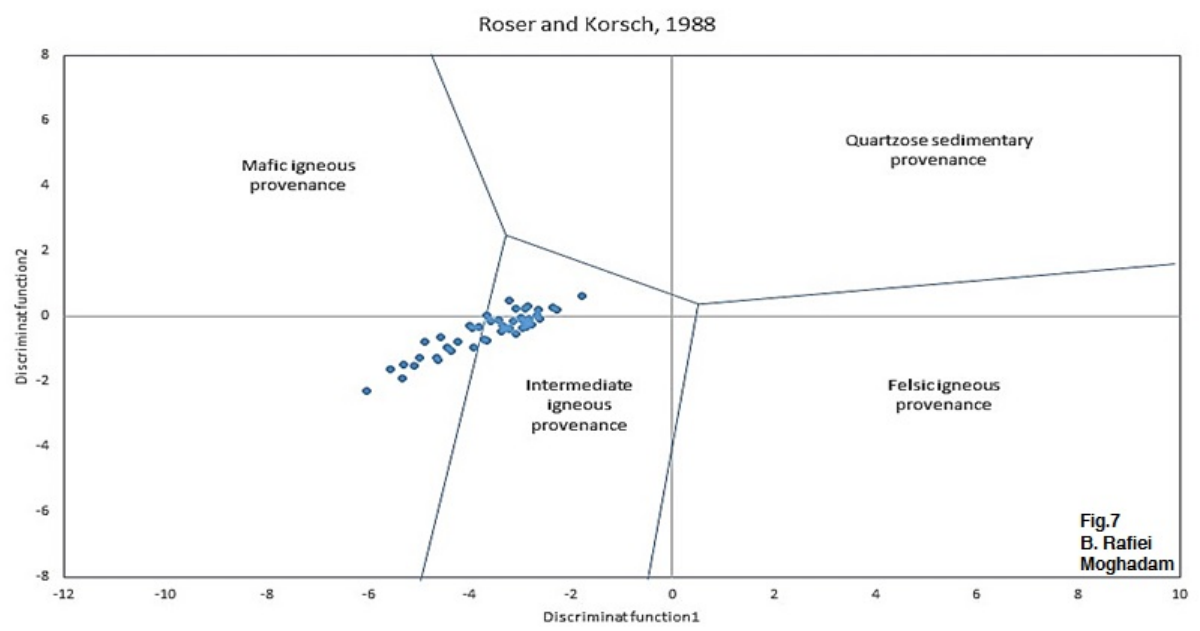

Fig. 7. Locating the samples taken from the Fenced Lagoon on the chart Roser and Korsch (1988).

Discriminant function I $=-1,773 \mathrm{TiO} 2+0,607 \mathrm{Al}_{2} \mathrm{O}_{3}+0,76 \mathrm{Fe}_{2} \mathrm{O}_{3}$ (total) $-1,5 \mathrm{MgO}+0,616 \mathrm{CaO}+0,509 \mathrm{Na}_{2} \mathrm{O}-1,224 \mathrm{~K}_{2} \mathrm{O}-9,09$;

Discriminant function II = 0,445 TiO2 + 0,07 $\mathrm{Al}_{2} \mathrm{O}_{3}-0,25 \mathrm{Fe}_{2} \mathrm{O}_{3}$ (total) $-1,142 \mathrm{MgO}+0,438 \mathrm{CaO}+1,475 \mathrm{Na}_{2} \mathrm{O}+1,426 \mathrm{~K}_{2} \mathrm{O}-6,861$

\section{Tectonic Location}

Determination of tectonic location is influenced by factors such as sedimentation, diagenesis and initial composition of sediment (Pettijohn et al., 1987; Bhatia, 1983; Chamley, 1990). Therefore, the main elements of the sand can be used to determine their tectonic position (Bhatia, 1983; Von Eynatten, 2003; Armstrong-Altrin and Verma 2005; Al-Juboury et al., 2009; Sahraeyan and Bahrami, 2012). As shown in Fig. 8, based on changes in the values of the main elements, the cranial rocks of oceanic arch islands, continental arch islands, active continental margin, and passive margin can be separated from each other. In (Roser and Korsch, 1986) diagram, major oxides of $\mathrm{SiO}_{2}, \mathrm{Al}_{2} \mathrm{O}_{3}, \mathrm{Na}_{2} \mathrm{O}$, and $\mathrm{K}_{2} \mathrm{O}$ are used to determine the longstanding tectonic location of sediments. With regard to Fig. 8, it appears that the Fenced Lagoon sands are more oriented to the continental arch islands. The reason for the displacement of the samples in relation to the determined limits can be the presence of $\mathrm{Fe}_{2} \mathrm{O}_{3}$ and $\mathrm{MgO}$ oxides. The presence of some $\mathrm{Al}_{2} \mathrm{O}_{3}$ can be due to the presence of particles containing iron and magnesium phyllosilicates.

In general, the summary of the graphs used to study the tectonic position of sedimentary rocks suggests that the sediments of the studied area are located in the continental arch islands and, to a lesser extent, in the active continental margin. The existence of a stable tectonics in the region has resulted in relatively regular geochemical data accumulation Adabi (2011). Therefore, with regard to petrographic and tectonic-stratigraphic evidence of the sediments in the region it can be concluded that these sediments have been deposited near the source. Geochemical study of surface sediments of the region indicates that there is a good correlation between frequency of elements and gradation and mineralogy in some elements. In fact, the destructive origin of sediments is the main contributor to the distribution of elements, especially heavy metals in the bed, and the anomaly of the concentration of the elements is mainly dependent on the mud blasters and the penetration of groundwater from the bed (Glazovski, 1991; Brusilovskii and Turuchkina 1974).

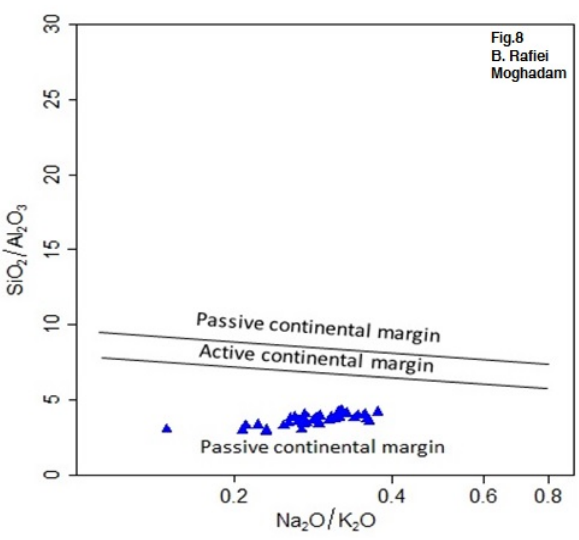

Fig. 8. The composition diagram of the main elements of the Fenced Lagoon sediments to determine the tectonic location of the deposits: Bhatia, 1983; Roser and Korsch, 1986

Conclusion. Sedimentary and geochemical studies of destructive deposits of the Fenced Lagoon were carried out to identify the source rock and tectonic location and the following results were obtained. Sediments of this lake were divided into four sedimentary types including Muddy Sand, Slightly Gravely Muddy Sand, Sand, and Slightly Gravely Sand, and sand is the main component of all these sediments. The most abundant sedimentary types belong to Muddy Sand and Sand and the least abundant sedimentary types belong to Slightly Gravely Muddy Sand and Slightly Gravely Sand. The frequency of Muddy Sand is mainly seen in surface sediments up to the depth of $100 \mathrm{~cm}$, while the facies type of Slightly Gravely Muddy Sand is related to grater depths and both facies are more abundant in the north and northeast parts of the lake. By moving to the south and southwest regions of the lake, the two facies of Sand and Muddy Sand become more abundant. The size of sediment particles increases as the depth decreases from northeast to southwest. Alternate layers of sand - mud and sand horizons containing shellfish represent the periods of relaxation of the lagoon and its relationship with the sea (Ghazban and Zare, 2010). The changes trends of the oxides of the main and trace elements against $\mathrm{Al} 2 \mathrm{O} 3$ 
indicate that the sediments under study can be classified into two general groups of sand and mud.A review of the charts to determine the nature of the origin rock suggests that the sediment samples of the Fenced Lagoon fall into different ranges of Mafic and Felsic origin rock, that is, they have acidic to intermediate combination.

The survey of the total graphs used to study the tectonic position of sediments indicates that the sediments of the studied area are located in the continental arch islands, and to a lesser extent, the active continental margin.

\section{Список використаних джерел / References}

Abdolahi Pour, F., Safahieh, A., Dadalahi, S., Pakzad, A., Tocheie, S. (2012). Determination of concentration of copper, lead, and nickel metals in the sediment of the tidal zone of Chabahar shores. Proceedings of the Fourth International Congress of Geographers of the World of Islam.

Abigail, C., Allwood, J.P., Grotzinger, A.H., Knoll, I.W., Burch, M.S. Anderson, M.L., Coleman, H., Isik, K. (2009). Controls on development and diversity of Early Archean stromatolites. A National Aeronautics and Space Administration Astrobiology Institute at the Jet Propulsion Laboratory. California Institute of Technology, Pasadena, 55-66.

Adams, D.C., Keller, G.R. (1994). Possible extension of the Midcontinent rift in west Texas and eastern New Mexico. Canadian Journal of Earth Science, 31, 709-720

Adabi, M.H. (2011). Sedimentary geochemistry. Second edition. Arian zamin publisher, Tehran.

Agha-Nabati, A. (2004). Iran's Geology. Geological survey of Iran. Tehran. Afarin, M., Bumry, M., Mahnubi, A. (2014). Sedimentary and geochemistry of siliciclastic sediments (tertiary and quaternary) west beach of Chabahar, South west of Sistan va Baluchestan. Journal of Geosinces, 24, 96, 85-96.

Alavi, M. (1996). Tectono stratigraphic synthesis and structural style of Alborz mountain system in northern Iran. J. Geodynamics, 21/1,1-33

Al-Juboury, A.I., Mccann, T., Ghazal, M.M. (2009). Provenance of Miocene sandstones in northern Iraq: constraints from framework petrography, bulk-rock geochemistry and mineral chemistry. Russian Geology and Geophysics, 50, 517-534

Amini, A., Moussavi-Harami, R., Lahijani, H., Mahboubi, A. (2012). Sedimentological, geochemical and geomorphological factors in formation of coastal dunes and nebkha fields in Miankaleh coastal barrier system (Southeast of Caspian Sea, North Iran). Geosciences Journal, 16/2, 139-152.

Anderson, K.J., Krysell, M. (2005). Dry matter (DM), loss on ignition (LOI) and total organic carbon (TOC). Report on an evaluation study.

Armstrong-Altrin, J.S., Verma, S.P. (2005). Critical evaluation of six tectonic setting discrimination diagrams using geochemical data of Neogene sediments from known tectonic Settings. Sedimentary Geology, 177, 1-2, 115-129.

Bahr, B. A., Lamy, F., Arz, H., Kuhlmann, H., Wefer, G. (2005). Late glacial to Holocene climate and sedimentation history in the NW Black Sea. Marine Geology, 214, 309-322.

Bhatia, M.R. (1983). Plate Tectonics and Geochemical Composition of Sandstones. Journal of Geology, 91, 611-627.

Bhatia, M.R., Crook, K.A.W. (1986). Trace Element Characteristics of Graywackes and Tectonic SettingDiscrimination of Sedimentary Basins. Contrib. mineral. Petrol., 92, 181-193.

Blott, S.J., Pye, K. (2001). GRADISTAT: A Grain Size Distribution and Statistic Package for the Analysis of Unconsolidated Sediments Surface Processes and Modern Environments Research Group. Department of Geology, Royal Holloway University of London, Egham, Surrey. TW20 0EX, UK, Earth Surface Processes and Landforms. Earth Surf. Process. Landforms 26, 1237-1248, 261.

Bruland, K.W. (2010). Geotrace Co Intercalibration Results. Retrieved fromlntercalibration/SAFe Co.pdf.

Brusilovskii, S.A., Turchkin, N.M. (1974). Microelemnts in ground water and in sediments at the west coast of middle Caspian. In: Leontiev, O.K. and Maev, E.G. (Eds.). Comprehensive Investigation of the Caspian Sea. Moscow State University Publication, Moscow, 4, 126-134.

Buccolieri, A., Cardelicchio, N., Dellatti, A., Di Leo, A., Macib, A. (2006). Heavy metals in marine sediments of Taranto Gulf (Ionian Sea, Southern Italy). Marine Chemistry, 99, 227-235.

Chamley, H. (1990). Sedimentology. Berlin: Springer-Verlag.

Dabard, M.P. (1990). Lower Brioverian Formations (Upper Proterozoic) of the Armorican Massif (France): Geodynamic evolution of source areas revealed by sandstone petrography and geochemistry. Sedimentary Geology, 69, 45-58

Das, B.K., Al-Mikhalfi, A.S., Kaur, P. (2006). Geochemistry of Mansar Lake sediment, Jammu, India, Implication for source-area weathering, provenance, and tectonic setting. Journal of Asian Earth Sciences, 26, 649-668.

Faiz Nia, S. (2008). Applied Sedimentology with Emphasis on Soil Erosion and Sediment Production. Gorgan University of Agricultural Sciences and Natural Resources.

Folk, R.L. (1980). Petrology of sedimentary racks. Hemphill Publishing Company Austin, Texas.

Folk, R.L., Ward, W.C. (1957). Brazos river bar: a study in the significance of grain size parameters. Journal of Sedimentary Petrology, 27, 3-26.

Folk, R. L., (1954). The distinction between grain size and mineral composition in sedimentary rock nomenclature. Jour. Geology, 62, 344-359.
Ghazban, F., Zare, M. (2011). Survey of the origin of heavy metals pollution in Bandar Anzali sediments (North of Iran). Environmental sciences, thirty and seventh year, $57,45-56$

Glazovski N.F. (1991). The Aral Crisis. Source, Current Situation and Way Out, USSR in the Perspective of Global Change. Polish Association for the Club of Rome, Warsaw, Globality versus Locality, 3, 167-199.

Gonenc, I.E., Wolfin, J.P. (2005). Coastal lagoons: ecosystem processes and modeling for sustainable use and development. CRC Press, Boca Raton, Florida, USA.

Hazer Moshar, A. (2015). Sedimentology and Hydrogeological Origin in Eynak Marsh (West of Rasht, Gilan Province). PhD Thesis. Faculty of Science, Islamic Azad University (North Tehran).

Hayashi, K.I., Fujisawa, H., Holland, H.D., Ohamoto, H. (1997). Geochemistry of approximately $1.9 \mathrm{Ga}$ sedimentary rocks from northeastern Labrador. Canada. Geochem Acta, 61, 4115-4137.

Jansen, J.H.F., Van Der Gasst, S.J., Koster, B., Vaars, A.J. (1998). CORTEX, a shipboard XRF-scanner for element analyses in split sediment cores. Mar. Geol.,151, 143-153.

Kakroodi, A.A., Krooneberg, S.B., Hoogendoorn, R.M., Mohammad Khani, H. Yamani, M., Ghassemi M. R., Lshijani, H.A.K. (2012). Rapid Holocene sea level changes along the Iranian Caspian coast. Quaternary International, 263, 93-103.

Karimkhani, A., Mohseni, H., Atashmard, Z. (2007). The role of sedimentological and geochemical indicators in the recognition of redox conditions in the southern part of the South Caspian Basin. Applied Sedimentology, 5/9,1-20.

Krooneberg, S.B., Abdurakhmanoy, G.M., Badyukova, E.N., Van Der Borg, K., Kalashnikov, A., Kasimov, N.S., Rychagov, G.I., Svitoch, A.A., Vonhof, H.B., Wesselingh, F.P. (2007). Solar-forced 2600 BP and Little Ice Age Highstands of the Caspian Sea Quaternary International, 137-143.

Kazanci, N., Turkmen, G., Ertunc, Ö., Gultutan, Y., Ekingen, P., Öz, B. (2008). A research on water quality of Kelkit stream using benthic macroinvertebrates and physicochemical variables. Rev. Hydrobio., 1/2, 145-160.

Kazancl, N., Gulbabazadeh, T., Leroy, S.A.G., Ileri, O. (2004) Sedimentary and environmental characteristic of the Gilan - Mazenderan plain, northern Iran: Influence of long and short-term Caspian water level fluctuation on geomorphology. Marine System, 46, 145-168.

Khabaznia, A.R., Khalatbari-Jafari, M. (2005). Geological map of the Birk2 Quadrangle. Scale $/ 100,000$. Published by Geological Survey of Iran (as supervisor)

Karageorgis, A., Anagnostou, Ch., Sioulas, A., Chronis, G., Papathanassiou, E. (2006). Sediment geochemistry and mineralogy in Milos Bay. SW Kyklades. Aegean Sea. Greece. Journal of Marine Systems, 16, 269-281.

Katemaunzanga, D. Gunter (2009). Lithostratigraphy, Sedimentology, and Provenance of the Balfour Formation (Beaufort Group) in the Fort BeaufortAlice Area, Eastern Cape Province, South Africa. Acta Geologica Sinica (English Edition), 83/5, 902-916.

Lahijani, H.A.K., Rahimpour Bonab, H , Tavakoli, V., Hosseindoost M. (2009). Evidence for Late Holocene high-stands in Central Gilān-East Mazanderan, South Caspian coast, Iran. Quaternary International, 197, 55-71.

Lak, R. (2015). Sedimentation study of areas susceptible to the production of rapeseed in the marginal lands of the northwest of Lake Urmia. Geological Survey of Iran.

Leeder, M.R. (1982). Sedimentology, processes and product. UNWIN HYMAN.

Lee, Y. (1999). Geochemical characteristics of the Manhang Formation (Late Carboniferous) sandstones, Korea: implication for provenance. Geosciences Journal, 3, 87-94.

Leontiev, O.K. (1977). Geomorphology of the Iranian coast of the Caspian Sea. Russian Academy of Sciences, 5/6, 20-25.

Leroy, S.A.G., Lahijanl, A.K., Djamali, M., Naqinezhad, A., Moghadam, M.V., Arpe, K. Shah-Hosseini, M. Hosseindoust, M., Miller, C.S., Tavakoli, V., Habibi, P. Naderi, M. (2011). Late Little Ice Age paleoenvironmental records from the Anzali and Amirkola lagoons (south CS): vegetation and sea level changes. Paleogeography, Paleoclimatology, Paleoecology, 302, 415-434.

Maynard, J.B. Valloni, R., Yu, H.S. (1982): Composition of modern deepsea sand from are related basins. Trench fore-arc Geology: Sedimentation and Tectonics on Modern and Ancient Active Plate Margins, Geological Society of America Special Paper.

Maslov, A.V. (2011). Lithogeochemistry of the fine-grained siliciclastic rocks of the Vendian Serebryanka Group of the Central Urals. Geochemistry International, ISSN: 0016-7029 (Print),12/152, 1556-1968.

McLennan, S.M., Hemming, S., McDaniel, D.K., Hanson, G.N. (1993). Geochemical approaches to sedimentation provenance and tectonics. In: Johnsson, M.J. and Basu, A (Eds.). Processes Controlling the Composition of Clastic Sediments. Geological Society of America, Boulder, Colorado, Special Paper 284, 21-40.

Moussavi-Harami, R. (2006). Sedimentology. Ninth edition. Astan Quds Razavi Publishing House.

Muller, D., Groves D.I. (1993). Direct and Indirect associations Between Potassic igneous rocks, shoshonites and gold-copper deposits. Ore Geol. Rev., 8, 383-406.

Naderi Beni, A., Lahijani, H. (2014). Late Holocene Caspian Sea Leve Changes and its Impacts on Low Lying Coastal Evolution: a Multidisciplinary Case Study from South Southeastern Flank of the Caspian Sea.Journal of the Persian Gulf (Marine Science), 5/16, 22, 27-48

Naderi Beni, A., Lahijani, H., Mousavi Harami, R., Leroy, S., ShahHosseini, M., Kabiri, K., Tavakoli, V. (2013). Development of spit-lagoon complexes in response to Little Ice Age rapid sea level changes in the central Gilān coast, South CS, Iran. Geomorphology, 187, 11-26. 
Nath, B.N., Kunzendorf, H., Pluger, W.L. (2000). Influence of Provenance, weathering and sedimentary processes on the elemental ratio of the finegrained fraction of the bed load sediments from the Veinbanad lake and the adjoining Continental shelf, southwest coast of in clim. Journal of Sedimentary Research, 70, 1081-1094.

Nazari, H., Omrani, J., Shahidi, A., Salamati, R., Moussavi, A. (2004). Geological map of Bandar-e- Anzali, 1: 100,000. Geological Survey of Iran.

Paseban, A. (2012). Sedimentary facies and slope changes of sediments towards downstream of basin of Sarghaye (south of Mashhad). Scientific Journal of Sedimentary Facies, 5/2, 153-168.

Pettijohn, F.J., Potter, P.E., Siever, R. (1987). Sand and Sandstone. 2nd ed. Springer-Verlag, New York.

Pettijohn, F.J. (1963). Chemical composition of sandstones, excluding carbonate and volcanic sands. Chap. S in date of geochemistry. 6th ed. U.S. Geological Survey, Professional Paper 440, 21P.

Pye, K. (1994). Properties of sediment particles. In Sediment Transport and Depositional Processes. Blackwell: Oxford, 1-24.

Ranjbar, M. (2012). Anzali Wetland Changes and its Morphological Characteristics in Land Use. Journal Of Geography of the land, 9/34, 93-111.

Rollinson, H.R. (1993). Using Geochemical Data: Evolution, Presentation, Interpretation. Longman.

Rice, S. (1999). The nature and controls on downstream fining within sedimentary link. J. Sediment. Res., 69A, 32-39.
Rohl, U., Abrams, L.J. (2000). High-resolution, downhole and nondestructive core measurements from Sites 999 and 1001 in the Caribbean Sea : Application to the late Palaeocene the maximum.Proc. Ocean Drill. Program Sci. Results,165, 191-203.

Roser, B.P., Korsch, R.J. (1988). Provenance signatures of sandstonemudstone suites determined using discriminant function analysis of majorelement data. Chemical Geology, 67, 119-139.

Roser, B.P., Korsch, R.J. (1986). Determination of tectonic setting of sandstone. Mudstone suites using $\mathrm{SiO}_{2}$ content and $\mathrm{K}_{2} \mathrm{O} / \mathrm{Na}_{2} \mathrm{O}$ ratio. Journal of Geology, 94, 635-650.

Sahraeyan, M., Bahramani, M. (2012). Geochemistry of sandstones from the Aghajari Formation, Folded Zagros Zone, southwestern Iran: Implication for paleo weathering condition, provenance, and tectonic setting. International Journal of Basic and Applied Sciences, 4, 390-407.

Tamura, A et al. (2008). Petrology and geochemistry of peridotites from IODP Site U1309 at Atlantis Massif, MAR $30^{\circ} \mathrm{N}$ : micro- and macro-scale melt penetrations into peridotites. Contributions to Mineralogy and Petrology, 155/4, 491-509.

Taylor, S.R., McLennan, S.M. (1985). The continental crust: its composition and evolution. Blackwell Science Publisher.

Von Eynatten, H. (2003). Petrography and chemistry of sandstone from the Swiss Molasse Basin: An archive of the Oligocene to Miocene evolution of the Central Alps. Sedimentology, 50, 703-724.

Надійшла до редколегії 13.03.20

Бехназ Рафій Могадам, асп.,

E-mail: bhnzrafiei@gmail.com

Халил Резай, асист.,

E-mail: drkhalilrezaei@gmail.com;

Алі Солгі, доц.,

E-mail: Asolgi66@yahoo.com;

Пантея Гхіачі, інструктор,

E-mail:aleali.mohsen@gmail.com;

Мохсен АлеАлі, асист.,

E-mail:pgiahchi@gmail.com;

Тегеран, Іран

\section{ДИФЕРЕНЦІАЦІЯ ТА ГЕОХІМІЯ ОСАДОВИХ ВІДКЛАДІВ ЛАГУН (БАНДАР-АНЗАЛІ) 3 УРАХУВАННЯМ МАТЕРИНСЬКИХ ГІРСЬКИХ ПОРІД І ТЕКТОНІЧНОЇ ОБСТАНОВКИ}

Розташування лагуни Фенсед у міському басейні Бандар-Анзалі вимагає дослідження з метою враховування впливу на життя людей регіону в контексті збереження водно-болотних угідь та екологічних систем. Потенціал цього району, який є центром геотуризму, визначає необхідність дослідження седиментології та геохімії району. Тому для вивчення осадових і геохімічних властивостей осадів лагуни Фенсед у Бандар-Анзалі було відібрано 33 зразки, а також проведено базові седиментаційні випробування та визначення вмісту важких металів за допомогою XRF. Результати показують, що зразки змінюються від піску до глинистої фрракції, а також мають переважно прибережно-річкове походження. Осади даного озера класифікуються за чотирма осадовими типами: грязьовий пісок, злегка насичений грязьовий пісок, пісок і важкий пісок. Пісок є основною складовою частиною всіх цих відкладень. Найбільи розповсюджені осадові типи належать до грязьового піску та піску, а найменш розповсюджені належать до злегка насиченого грязьового піску та важкого піску. Характер вихідної породи залежить від кислої до проміжної комбінації, і загалом осадові породи досліджуваної території лежать у межах континентальних дугових островів. Меншою мірою відносяться до активної окраїни континенту.

Ключові слова: порт Анзалі, осади, осадова геохімія, важкі метали, походження, тектонічне розташування.

Бехназ Рафий Могадам, асп.,

E-mail:bhnzrafiei@gmail.com;

Халил Резай, ассист.,

E-mail:drkhalilrezaei@gmail.com;

Али Солги, доц.,

E-mail: Asolgi66@yahoo.com;

Пантея Гхиачи, инструктор,

E-mail: aleali.mohsen@gmail.com;

Мохсен АлеАли, ассист.

E-mail: pgiahchi@gmail.com;

Тегеран, Иран;

\section{ДИФФЕРЕНЦИАЦИЯ И ГЕОХИМИЯ ОСАДОЧНЫХ ОТЛОЖЕНИЙ ЛАГУН (БАНДАР-АНЗАЛИ) С УЧЕТОМ МАТЕРИНСКИХ ГОРНЫХ ПОРОД И ТЕКТОНИЧЕСКОЙ ОБСТАНОВКИ}

Расположение лагуны Фенсед в городском бассейне Энзели требует исследования, чтобы учесть влияние на жизнь людей региона в контексте сохранения водно-болотных угодий и экологических систем. Потенциал этого района, который является центром геотуризма, определяет необходимость исследования седиментологии и геохимии района. Поэтому для изучения осадочных и геохимических свойств осадков лагуны Фенсед в Энзели было отобрано 33 образца, а также проведены базовые седиментационные исследования и определения содержания тяжелых металлов с помощью XRF. Результаты показывают, что образцы меняются от песка до глинистой фракции, а также имеют преимущественно прибрежно-речное происхождения. Осадки данного озера классифицируются по четырем осадочным типам: грязевой песок, слегка насыщенный грязевой песок, песок и тяжелый песок. Песок является основной составной частью всех этих отложений. Наиболее распространенные осадочные типы относятся к грязевым пескам и пескам, а наименее распространенные относятся к слегка насыщенному грязевому песку и тяжелому песку. Характер исходной породы зависит от кислой к промежуточной комбинации, а осадочные породы исследуемой территории находятся в пределах континентальных дуговых островов. В меньшей степени относятся к активной окраине континента.

Ключевые слова: порт Анзали, осадочные породы, осадочная геохимия, тяжелые металлы, происхождение, тектоническое расположения. 